\title{
Persepsi Petani terhadap Ketersediaan Sarana dan Prasarana Usahatani di Subak Babakan Bengkel I Desa Getasan Kecamatan Petang Kabupaten Badung
}

\author{
I GEDE BAGUS ARYADHANA, NI WAYAN SRI ASTITI, \\ I DEWA PUTU OKA SUARDI
}

\author{
Program Studi Agribisnis Fakultas Pertanian Universitas Udayana \\ Jalan P.B. Sudirman Denpasar 80232 \\ E-mail : degusaryadhana93@gmail.com \\ wayansriastiti@yahoo.co.id
}

\begin{abstract}
Perception Farmers Against Availability Infrastructures in Subak Babakan Bengkel I Village Getasan Sub District Petang Badung.
\end{abstract}

Agriculture in a broad sense includes smallholder agriculture, plantation, forestry, animal husbandry and fishery. Facilities and infrastructure are all things that are used as a tool in achieving the objectives of farmers in Subak Babakan Bengkel I Village Getasan to support developments in running the farm. Based on this expected that the developments in the availability of facilities and infrastructure in the farming. Based on the above problems, the purpose of this study was to determine the perception of farmers on the availability of facilities and infrastructure of farming in Subak Babakan Bengkel I Village Getasan Sub District Petang Badung. To prepare a good questionnaire required some testing prior to conducting the study. Testing the questionnaire using SPSS. The variable in this study is the perception of farmers on the availability of facilities and infrastructure of farming in Subak Babakan Bengkel I Village Getasan Sub District Petang Badung. Indicators of this study include the availability of means of production, namely seeds, fertilizers, pesticides, plant growth regulator and inoculant. Alsintan (agricultural machinery), ie sprayer, power weeder, emposan tikus, reaper, tractors and power threaser. Network infrastructure includes farm roads, halls Subak, and irrigation canals. To maintain and increase the availability of facilities and infrastructure in Subak Babakan Bengkel I of both categories should be excellent farmers complementary facilities and infrastructure that can greatly help in a time efficient and agricultural work in Subak

Keywords: infrastructure, facilities, subak, rice

\section{Pendahuluan}

\subsection{Latar Belakang}

Pertanian dalam arti luas meliputi pertanian rakyat, perkebunan, kehutanan, peternakan, dan perikanan. Mewujudkan pertanian yang maju maka perlu adanya pembangunan pertanian. Indonesia merupakan negara agraris artinya pertanian memegang peranan penting dari keseluruhan perekonomian nasional. Hal ini dapat ditunjukkan dari banyaknya penduduk atau tenaga kerja yang hidup dan bekerja pada sektor pertanian (Mubyarto, 1986). Pembangunan pertanian merupakan dasar utama 
dalam pembangunan nasional untuk mewujudkan perekonomian nasional yang mandiri dan handal.

Sistem pertanian di Bali, khususnya usahatani padi sangat berkaitan erat dengan subak. Subak merupakan organisasi yang mengatur tentang sistem pengairan sawah yang ada di Bali. Sistem pengairan ini sudah dikenal kurang lebih dari satu abad yang lalu. Semua hal tentang pertanian mulai dari tanah, perairan, pemupukan, bagi hasil sampai pajakpun telah diatur (Windia, 2006). Subak Babakan Bengkel I terletak di Desa Getasan, Kecamatan Petang, Kabupaten Badung dibagi menjadi empat munduk yaitu (1) Munduk Bengkel, (2) Munduk Babakan, (3) Munduk Apit Bingin, dan (4) Munduk Kembengan. Luas keseluruhan lahan 90 hektar, dan jumlah anggota sebanyak 157 orang. Subak Babakan Bengkel I Desa Getasan mempunyai tanggung jawab dalam berusahatani untuk memproduksi pangan khususnya bagi penduduk Desa Getasan. Subak Babakan Bengkel I mengusahakan lahan pertanian yaitu lahan sawah basah dalam berusahatani. Petani adalah produsen pangan dan juga sekaligus kelompok konsumen terbesar yang sebagian masih miskin dan membutuhkan daya beli yang cukup untuk membeli pangan. Petani harus memiliki kemampuan untuk memproduksi pangan sekaligus ketersediaan sarana dan prasarana yang baik sehingga dapat memiliki pendapatan yang cukup untuk memenuhi kebutuhan pangan mereka sendiri.

Berdasarkan hal tersebut diharapkan adanya perkembangan ketersediaan sarana dan prasarana dalam usahatani, hal ini sangat dipengaruhi oleh persepsi yang positif dari petani terhadap perkembangan sarana dan prasarana. Maka dari itu peranan petani sangat diharapkan untuk perkembangan ketersediaan sarana dan prasarana usahatani di Subak Babakan Bengkel I. Berkaitan dengan hal tersebut sangat penting untuk dikaji bagaimanakah persepsi petani terhadap ketersediaan sarana dan prasarana usahatani di Subak Babakan Bengkel I Desa Getasan Kecamatan Petang Kabupaten Badung.

\subsection{Tujuan Penelitian}

Tujuan dari penelitian ini adalah untuk mengetahui persepsi petani terhadap ketersediaan sarana dan prasarana usahatani di Subak Babakan Bengkel I Desa Getasan Kecamatan Petang Kabupaten Badung.

\section{Metode Penelitian}

\subsection{Lokasi dan Waktu Penelitian}

Desa Getasan, Kecamatan Petang, Kabupaten Badung menjadi lokasi penelitian yang dimulai pada bulan September 2015. Penentuan lokasi penelitian tersebut menggunakan teknik purposive (sengaja) yang didasarkan atas pertimbangan prestasi Subak Babakan Bengkel I Desa Getasan yang mendapatkan peringkat I dalam Evaluasi dan Penghargaan Ketahanan Pangan se-Kabupaten Badung sehingga sangat baik untuk diteliti persepsi petani terhadap ketersediaan sarana dan prasarananya.

\subsection{Penentuan Populasi dan Sampel}

Populasi dari penelitian ini adalah anggota Subak Babakan Bengkel I Desa Getasan, jumlah petani yang berada di Subak Babakan Bengkel I berjumlah 157 orang yang terbagi dalam 4 munduk/blok. 


\subsection{Teknik Pengumpulan Data, Instrumen Pengumpulan Data, Variabel Penelitian dan Metode Analisis}

Teknik pengumpulan data yang digunakan yaitu teknik observasi, wawancara, dan dokumentasi. Instrumen pengumpulan data yang dipergunakan dalam peneletian ini yaitu berupa kuesioner yang telah dilakukan melalui uji validitas dan uji realibilitas dengan nilai masing-masing. Variabel pada penelitian ini adalah pengetahuan petani tentang pupuk organik, sikap petani dalam pemanfaatan pupuk organik, dan penerapan petani dalam menggunakan pupuk organik. Metode analisis yang dipergunakan adalah analisis deskriptif kualitatif dan kuantitatif.

\section{Hasil dan Pembahasan}

\subsection{Karakteristik Responden}

Karakteristik responden dalam penelitian ini meliputi umur, tingkat pendidikan formal, mata pencaharian, dan luas lahan garapan.

\subsubsection{Umur}

Hasil penelitian menunjukkan bahwa rata-rata responden berusia 44,2 tahun, dengan sebagian besar responden tergolong kategori umur masa lansia awal dengan presentase $(41,2 \%)$. Rataan usia tersebut menujukkan para petani telah memiliki pengalaman yang relatif lama dalam menekuni kegiatan pertanian di Subak Babakan Bengkel I.

\subsubsection{Tingkat pendidikan formal}

Tingkat pendidikan yang memadai membuat petani akan semakin mengerti dan memahami materi-materi yang disampaikan oleh penyuluh serta mempengaruhi kemampuan petani untuk menerima inovasi baru (Thoha, 2004). Hal ini dapat dilihat dari pendidikan dasar sembilan tahun yang dikenyam responden lebih banyak, yaitu sebanyak 16 orang $(47 \%)$ dari responden yang mengenyam pendidikan SMA yaitu sebanyak 15 orang (53\%). Hal ini berarti responden petani di Subak Babakan Bengkel I memiliki kemampuan yang kurang baik dalam menerima suatu pengetahuan baru. Beberapa petani tersebut akan menyebabkan tejadinya perilaku penolakan terhadap inovasi ketersediaan sarana dan prasarana baru yang diberikan oleh penyuluh atau pemerintah dan lebih cenderung tetap melanjutkan sistem yang mereka tekuni, tanpa mencoba inovasi yang baru.

\subsubsection{Mata pencaharian}

Dapat diketahui presentase mata pencaharian pokok responden sebagai petani yaitu sebanyak 34 orang (100\%). Pekerjaan sampingan yang dimiliki oleh responden adalah wiraswasta $(29,4 \%)$, buruh $(5,8 \%)$ dan sebagian besar responden tidak memiliki pekerjaan sampingan $(64,7 \%)$. Pekerjaan sampingan sebagai wiraswasta dan buruh yang dijalankan responden semata-mata karena responden merasa penghasilan sebagai petani masih belum cukup untuk memenuhi kebutuhan, sedangkan responden yang tidak memiliki pekerjaan sampingan mempunyai alasan bahwa mereka menjadi petani sudah cukup untuk memenuhi kebutuhan keluarga.

\subsubsection{Jumlah anggota keluarga}

Hasil penelitian menunjukkan bahwa jumlah keluarga responden rata-rata 4,12 dalam satu rumah tangga. Sebanyak 33 responden rumah tangga $(97 \%)$ tergolong ke 
dalam kelompok dengan anggota keluarga antara tiga hingga lima orang dan sebanyak satu rumah tangga (3\%) yang beranggotakan lebih dari lima orang. Pendapatan keluarga lebih banyak didapatkan dari hasil pekerjaan pokok responden itu sendiri

\subsubsection{Pemilikan dan penguasaan lahan}

Rata-rata luas lahan sawah yang dimiliki oleh responden seluas 31,4 are, sedangkan luas lahan tegalan dan lahan pekarangan yang dimiliki responden seluas 8,1 are lahan tegalan dan 17,6 are lahan pekarangan. Lahan tegalan dan pekarangan tersebut umumnya dimanfaatkan sebagai bangunan rumah dan sisanya untuk menanam tanaman.

\subsection{Persepsi Petani terhadap Ketersediaan Sarana Produksi}

Penelitian ini mengkaji tentang persepsi yang dilihat dari ketersediaan sarana produksi, yang diukur melalui jumlah ketersediaan sarana produksi, waktu ketersediaan sarana produksi, kualitas sarana produksi, dan keterjangkauan harga sarana produksi. Indikator yang diukur antara lain, 1) ketersediaan bibit, 2) ketersediaan pupuk organik padat, 3) ketersediaan pupuk organik cair, 4) ketersediaan pupuk non organik, 5) ketersediaan pestisida, 6) ketersediaan ZPT (zat pengatur tumbuh), dan 7) ketersediaan inokulan. Hasil penelitian menunjukkan bahwa persepsi petani terhadap ketersediaan sarana produksi termasuk dalam kategori baik dengan pencapaian skor 3,81.

\subsubsection{Persepsi petani terhadap ketersediaan Alsintan (Alat Mesin Pertanian)}

Hasil penelitian menunjukkan bahwa persepsi petani terhadap ketersediaan Alsintan (alat mesin pertanian) tergolong dalam kategori sedang dengan rata-rata pencapaian skor sebesar 3,15. Kategori sedang yang dilihat dari ketersediaan Alsintan (alat mesin pertanian), diukur melalui ketersediaan dan keterjangkauan harga Alsintan. Indikator yang di ukur antara lain, 1) Ketersediaan sprayer, 2) Ketersediaan power weeder, 3) Ketersediaan emposan tikus, 4) Ketersediaan reaper, 5) Ketersediaan traktor, dan 6) Ketersediaan power threaser.

\subsubsection{Persepsi petani terhadap ketersediaan jaringan infrastruktur}

Persepsi petani terhadap ketersediaan jaringan infrastruktur termasuk kategori baik dengan rata-rata pencapaian skor 3,57. Kategori baik yang dilihat dari ketersediaan jaringan infrastruktur ini, diukur melalui kualitas ketersediaan sarana infrastruktur tradisional, semi permanen, dan permanen yang ada di subak Babakan Bengkel I. Indikator yang di ukur antara lain, 1) Ketersediaan jalan usahatani, 2) Ketersediaan balai subak, 3) Ketersediaan bendung (empelan), 4) Ketersediaan saluran tersier, 5) Ketersediaan bangunan-bagi (tembuku) pada saluran primer dan sekunder, 6) Ketersediaan bangunan-bagi (tembuku) pada saluran tersier, 7) Bangunan pengambil air pada setiap blok/komplek sawah petani, dan 8) Saluran drainase pada setiap blok/komplek sawah individual petani.

\section{Simpulan dan Saran}

\subsection{Simpulan}

Adapun kesimpulan dari penelitian ini adalah :

1. Persepsi petani terhadap sarana produksi termasuk kategori baik, dengan pencapaian skor 3,81 .

2. Persepsi petani terhadap prasarana alsintan termasuk kategori sedang, dengan pencapaian skor 3,15 . 
3. Persepsi petani terhadap prasarana jaringan infrastruktur termasuk kategori baik, dengan pencapaian skor 3,57.

\subsection{Saran}

Berdasarkan hasil pembahasan dan simpulan tersebut dapat disarankan sebagai berikut.

1. Sebaiknya pemerintah mengadakan pelatihan tentang penggunaan power weeder sehingga para petani terampil menggunakan power weeder, dengan demikian petani dapat memanfaatkan power weeder yang diberikan pemerintah.

2. Disarankan pula pengadaan jalan usahatani yang lebih baik sehingga memudahkan akses keluar masuk petani dalam kegiatan usahataninya.

\section{Ucapan Terima Kasih}

Penulis menyampaikan terima kasih kepada pengurus Subak Babakan Bengkel I beserta anggotanya yang telah memberikan data penelitian dan semua pihak yang telah membantu dan memberikan dukungan baik secara moril maupun dalam proses penelitian dan tersusunnya e-jurnal ini.

\section{Daftar pustaka}

Andika, I.G.O.A. 2014. Persepsi Pemuda terhadap Pekerjaan pada Sektor Pertanian di Desa Wisata Pangsan Kecamatan Petang Kabupaten Badung. Skripsi. Denpasar : Konsentrasi Pengembangan Masyarakat, Program Studi Agribisnis, Fakultas Pertanian, Universitas Udayana.

Ardana, K, N, W . Mujiati dan A. A. A. Sriathi. 2009. Perilaku Keorganisasian Edisi Kedua. Yogyakarta : Graha Ilmu.

Aryawati, N.M.D. 1994. Persepsi Masyarakat Petani terhadap Pekerjaan pada Sektor Pertanian di Daerah Pariwisata

BPS Indonesia. 2013. Jumlah Tenaga Kerja Sektor Pertanian di Indonesia. \{Internet\}. (http:// www. bps. Go. Id./ brs_file/ naker_07mei12. Pdf. Diunduh pada tanggal 11 Juli 2015

BPS Provinsi Bali Keadaan Ketenagakerjaan Provinsi Bali Februari 2013. \{Internet\} http://bali.bps.go.id/brs/naker/brs_naker_05_2013.pdf. Diunduh pada tanggal 11 Juli 2015.

BPS Provinsi Bali. 2015. Bali dalam Angka (Bali In Figures) 2015. Denpasar : UD Sarana Ilmu.

Mubyarto. 1986. Pengantar Ekonomi Pertanian Jakarta. Lembaga Penelitian Pendidikan dan Penerapan Ekonomi dan Sosial.

Rosdiana, 2013. Faktor-Faktor yang Mempengaruhi Pengetahuan Siswa-Siswi tentang Keluarga Broken Home di Sekolah Menengah Atas Negeri 1 Meureudu Kabupaten Pidie Jaya. \{Jurnal Online\}. Internet. Diunduh pada tanggal 18 Februari 2016.

Thoha, M. 2004. Perilaku Organisasi. Rajawali Press. Jakarta.

Windia. 2006. Transformasi Sistem Irigasi Subak yang Berlandaskan Konsep Tri Hita

Karana. Denpasar : Pustaka Bali Post. 